\title{
TRANSFORMING ISLAMIC VALUES INTO CIVIC EDUCATION
}

\author{
By Samsuri
}

Abstrak

Artikel ini menyajikan kajian pendabuluan tentang penafsiran Islam sebagai sebuah system nilai yang diperlukan dalam pengkajian Pendidikan Kewarganegaraan di perguruan tinggi Islam Indonesia. Dalam kajian ini, contoh inspirasi Islam dalam Pendidikan Kewarganegaraan di perguruan tinggi Islam mengambil kasus di Universitas Islam Negeri Syarif Hidayatullah Jakarta dan Universitas Muhammadiyah Yogyakarta sebagai pelopor pengembangan Pendidikan Kewarganegaraan di lingkungan Perguruan Tinggi Mubammadiyah. Dalam artikel ini, penulis menelusuri kerangka pembaharuan pemikiran Islam tentang gagasan-gagasan demokrasi, hak asasi manusia, dan masyarakat madani (civil society) yang juga turut mempengarubi pengembangan Pendidikan Kewarganegaraan di kedua institusi yang dikaji. Dari kajian dokumentasi berupa buku bahan ajar Pendidikan Kewarganegaraan di kedua institusi tersebut, transformasi nilai-nilai ke-Islam-an ke dalam Pendidikan Kewarganegaraan memiliki sumbangan penting tentang pemaknaan upaya membentuk warga negara yang baik dengan identitas Islam.
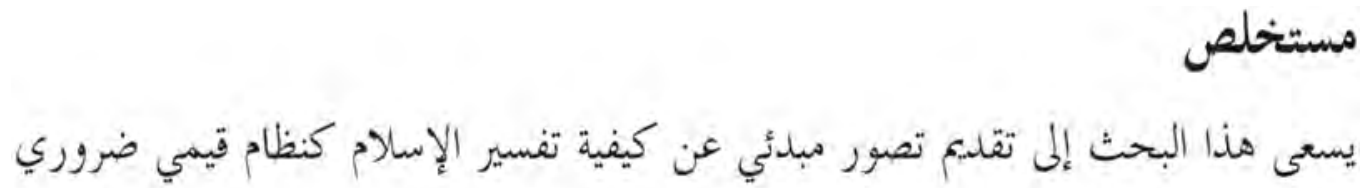
في إطار تدريس مادة الثربية القومية في مؤسسات التعليم العالي في إندو ئيسيا. تتناول المقالة حالثين دراسيتين هما حالة جامعة شريف هداية الله الإسالامية الحكومية في جاكرتا، والجامعة الحمدية في جوكجاكرتا؛ حيث يسلط الباحث الضوء على الإطار الفكري

Lecturer at the Yogyakarta State University (UNY), Yogyakarta, Indonesia. Email address: samsuri@uny.ac.id 


\section{الإسلامي التجديدي فيما يخص تدريس موضوعات الديمقر اطية وحقوق الإنسان والمختمع المدني في كل من الجامعتين المذكورتين. \\ وعبر دراسة وثائقية للمواد المدرِّة في الجامعتين، ينتهي البحث إلى أن اسثدماج القيم الإسلامية في تدريس مادة التربية القومية من شأنه أن يعزز من بناء المواطن الصالح عبر تقديمه لإطار تفسيري ذي معنى يسهم في إرساء دعائم الهوية القومية دون مساس بالهوية الإسمالاية.}

Keywords: Nilai-nilai Islam, Civil Society, dan Pendidikan Kewarganegaraan

\section{A. Introduction}

Indonesia as biggest Muslim population country in the world has faced new challenging post-authoritarian regime, new order period under President Soeharto. After 32 years under Soeharto administration, since May 1998 the country entered the transition to democracy. This new era, most known called as reformation order, has opportunity for civil society movement which be pressured under New Order regime to achieve the goals of reformation.

For Islamic movements, this period opened to actualize their aspirations. As known, they have limited activity to express ideals of democracy in all fields. Robert Hefner $(2000)^{1}$ noted many Islamic movements, as mainstream under Soeharto, legitimized the power for their surviving. Policy to accepting Pancasila as sole based for non-government organizations (and all political parties too), according to Islamic civil movement like Muhammadiyah and NU, made them have to change their principles (asas) with Pancasila. As known, Indonesia constitution addressed that it is not religion or secular state. But, it recognized the freedom rights to religion adherents express their faiths. Formally the state recognized the existing of big religious around the world in Indonesia, which be followed by majority of Indonesian people. They are Buddhism, Catholicism, Hinduism, Islam, and Protestanism. Following the President Soeharto addressing (in Krissantono, 1976) ${ }^{2}$ before P4 released, explicitly

1 Robert Hefner, Civil Islam: Muslims and Democratization in Indonesia, (Princeton-Oxford: Princeton University Press, 2000).

2 Krissantono, (ed.) Pandangan Presiden Soeharto tentang Pancasila, (Jakarta: CSIS, 1976) 
the government of Indonesia declared that it is nor based religion neither secular values. Another word, Indonesia is nor religion state neither secular state. These statements have been ambiguity when government then should create the Religions Affair Department in its administration. In the living public, the people must have ID card which printed their faith religion. This condition nearly what Robert N. Bellah $(1976)^{3}$ mentioned on civil religion in United Stated of America context. Really, I looked at Pancasila similarly as civil religion to transcend the formal religions in Indonesia as biggest Muslim population country around the world.

Study of Faisal Ismail (1995) $)^{4}$ explained how Indonesian Muslims respond to Pancasila in three kinds. Firstly, Muslims respond it when nationalist-secular group addressed Pancasila as sole based of country near Indonesian independent 1945 and sessions of Constitution Assembly (Majelis Konstituante) at 1956 to1959. Secondly, the responding to Pancasila happened when New Order government issued the P4 to be released. Early time Muslims respond to P4 are negative, then their majority accept it. Last, third, when 1982 discourse of Pancasila as single sole based for NGOs and political parties has increased tensions between government and Muslims. Islamic organizations like Muhammadiyah and NU have to change their principle of mission, Islam, with Pancasila. After 1985, then most Islamic organizations accepted the law on Pancasila as single principle for them with multi-interpretation and strategic reasons.

In the educational field, regulation on religious education and Pancasila education (included civic education) released as core contents of curriculum for each educational level since kindergarten, primary school to university. Bill of national education system at 1989 has been released to amend old bill on education. For few Islamic education institutions, Pancasila education has been taught with Islamic values perspective when described the first principle of Pancasila, Ketubanan Yang Maha Esa (Believe One God). Civic education as part of Pancasila education has been reduced as kind of political indoctrination to support the regime interpretation on P4 and its policy.

Hefner $(2000)^{5}$ noted that democratic movements by Islamic organizations such as Nahdlatul Ulama and Muhammadiyah have signification after 1990s. In the

3 Robert N. Bellah, "Religion and the Legitimation of the American Republic", in Robert N. Bellah \& Phillip E. Hammond, (eds) Varieties of Civil Religion, (San Francisco: Harper \& Row, 1976)

4 Faisal Ismail, Ideologi Hegemoni dan Otoritas Agama: Wacana Ketegangan Kreatif antara Islam dan Pancasila [Hegemonic Ideology and Religious Authority: Creative Tension Discourse between Islam and Pancasila] (Yogyakarta: Tiara Wacana, 1999)

5 Robert Hefner, Civil Islam..., Ibid. 
Soeharto period at the New Order regime, Islamic movements have accentuations to actualization of Islamic values in the broader fields, either political (structural) Islam or cultural Islam movements. The civil society organizations emerged as reaction to empowered the grassroots which be weak

Education regulation has important meaning to look for what Islamic institution particularly Islamic higher education institutions developed the democratic transition to democratic citizens through civic education formally. In this paper, there are two Islamic institution which expansive to support CE teaching and learning models. For these cases, I found UIN Jakarta and Muhammadiyah through its universities have developed the CE models as new trend of Islamic education institution to respond global and domestic issues on democratization, human rights, gender equity, and so on, which accommodated Islamic values as basic or core contents.

\section{B. Trends of Islamic Thought Schools in Modern Indonesia}

Islamic education institutions in Indonesia has established long before proclamation of independence at August 17, 1945. Early educational models is madrasah which be called as pesantren. Pesantrens taught Islamic teaching more classics orientation on fiqh, grammatical of Arabic language, sufi teachings and practices. In the colonial period, Muhammadiyah as modernist Islamic movement has pioneered the western educational model which opened the schooling models.

After 1945, Islamic education institutions has transformed to follow Western education models by schooling models. Islamic teaching by western school model opened in the higher educational institution in $1960 \mathrm{such}$ as State Institute of Islamic Studies (IAIN). Greg Barton (1997: 42) ${ }^{6}$ mentioned that the reform of Islam has contributed to the formation of the IAIN, beginning with IAIN Syarif Hidayatullah, Jakarta, and IAIN Sunan Kalijaga, Yogyakarta in 1960.

In the beginning of IAIN, Islamic studies more texts-minded to study Islamic teachings. It nearest to Al-Azhar University teaching model in Egypt on Islamic studies approaches, which more scripturalistics to examine the Islamic sources. The individuals influencing and intellectual reformers, such as Harun Nasution in IAIN

6 Greg Barton, “Indonesia's Nurcholish Madjid and Abdurrahman Wahid as Intellectual 'Ulama: The Meeting of Islamic Traditionalism and Modernism in Neo-modernist Thought", in Studia Islamika: Indonesian Journal for Islamic Studies, Vol. 4. No. 1 1997, pp. 29-81. 
Jakarta and Abdul Mukti Ali in IAIN Yogyakarta, have been IAIN faced a process of liberal education and intellectual reforms (Barton, 1997: 42). ${ }^{7}$

Budhy Munawar-Rachman $(1995)^{8}$ mentioned that Islamic thought in Indonesia in 25 year (1995) after 1970 has riched themes. Its issues did not political dimension only, but it entered to cultural, theological, and philosophy fields. I agree with Munawar-Rachman (1995) opinion on mapping the Islamic thought into three big groups from Islamic neo-modernism thinkers in Indonesia. He categorized them as follows: Islam rasional (Islamic rational), Islam peradaban (Civilization Islam), and Islam transformatif (Transformative Islam) (Munawar-Rachman, 1995). ${ }^{9}$ They are Harun Nasution \& Djohan Effendi, Nurcholish Madjid \& Kuntowijoyo, and Adi Sasono \& Muhammad Dawam Rahardjo.

Another side, some observers agreed that Harun Nasution and Mukti Ali have opened new horizons to Islamic studies in the Muslims post-1970s. The new generation post Harun and Mukti Ali at IAIN are born in the early 1970s. Zuly Qodir (2002) called two mazhabs for two IAIN which have influenced Islamic thoughts in Indonesia, there are Mą̧ab Ciputat (IAIN Jakarta, now UIN Jakarta) and Mazhab Sapen (IAIN Yogyakarta, now UIN Yogyakarta). What differentiation of both? Qodir (2002: 340) ${ }^{10}$ mentioned that Mą̧ab Ciputat has efforted to reinterpretation the Islamic understanding types according to new approaches of Qur'an and hadith studies. Those approaches more contextual and sophisticated to Islamic studies. Mazhab Ciputat spreads the new mazhab that is "Mazhab Pluralis-Inklusif-Toleran" (Pluralist-Inclusive-Tolerance Schools). This mazhab introduced the new way to religiosity, especially Islam, in plural community. Some intellectuals who categorized as Mąhab Ciputat are Munawir Sjadzali, Nurcholish Madjid, Azyumardi Azra, Komaruddin Hidayat, Bahtiar Effendy and Kautsar Azhari Noer. They are active either IAIN staffs or civil society groups like Paramadina, Muhammadiyah and NU organizations.

Mazhab Sapen dominated Islamic thoughts either "traditionalists" or "modernists" scholars background. In the campus of IAIN Yogyakarta, Mą̧ hab

7 Ibid.

8 Buddhy Munawar-Rachman, "Dari Tahapan Moral ke Periode Sejarah Pemikiran NeoModernisme Islam di Indonesia", dalam Ulumul Qur'an, Vol. VI, No. 3 1995, pp. 4-29.

9 Ibid.

10 Zuly Qodir, "Wajah Islam Liberal di Indonesia: Sebuah Penjajagan Awal”, dalam Al-Jamiah: Journal of Islamic Studies, Vol. 40, No. 2, July-Dec. 2002, pp. 325-353. 
Sapen most dominated the intellectuals who have Muhammadiyah's background as their Islamic organizations. Those some people are M. Amin Abdullah (Rector of IAIN Yogyakarta), Abdul Munir Mulkhan (professor of sociology of religion, IAIN Yogyakarta) and Musya Asy'arie (professor of economic and Islamic philosophy, IAIN Yogyakarta). This Muhammadiyah group which be categorized as Mąhab Sapen, according to Qodir (2002), ${ }^{11}$ has called "Left-Muhammadiyah Activists" or "Muhammadiyah Liberal" because they most critical about themselves organization to interprete and search the social context for religiosity in the plural community.

Another group who categorized the Mą̧ab Sapen, according to Qodir $(2002)^{12}$ is the people whose Nabdlatul Ulama (NU, Islamic scholars association) background such as Machasin and Faisal Ismail in campuss and young intellectuals of NU who graduated from IAIN Yogyakarta and then built the critical Islamic studies in Lembaga Kajian Islam dan Sosial (Institution of Islam and Social Studies) Yogyakarta. This group developed the new horizon to understand on Islamic teaching with new approaching which introduced by the Muslim intellectuals such as Muhammad 'Abid al-Jabiri, Nasr Hamid Abu Zayd, Mohammed Arkoun, Hassan Hanafi, Muhammad Syahrur, Abdullahi Ahmed An-Naim and Muhammad Mahmud Thaha.

In the civil society movements, both groups has contributed to revitalized the Islamic teachings as substance of Islamic society in the Indonesian society pluralism context. The contemporary living issues in Indonesia like democratization, gender equity, religions relationship, and human rights have emerged in their movements.

\section{Developing Civic Education Based Islamic Values}

State Islamic University (UIN) of Syarif Hidayatullah, Jakarta

UIN Jakarta has pioneered new paradigm of CE in the higher education institution. Difference with CE which be developed by Higher Education Directorate of Ministry of National Education, CE in UIN Jakarta accomodated the universal concepts on CE. Following the CE model which be introduced by Center for Civic Education, Calabasas, California, USA, ICCE Team at UIN Jakarta succeded improving contents 
and teaching and learning model in university level. Islam as basic values for CE has meaning contribution for reforming the old paradigm of CE. Old paradigm of CE in university level has militaristic nuanced, and non participative.

At UIN Syarif Hidayatullah, Jakarta, contents of CE focused on three aspects those are democracy, human rights and civil society. For that, UIN has published a textbook and supplement textbook on CE. CE textbook contents the topics those are national identity, state and citizenship, constitution, democracy, regional autonomy, good governance, human rights and civil society.

Supplement of textbook arranged to fullfil the teaching and learning resources which has relevancy with socio-political contexts. Supplement contents 46 themes for nine subjects. Themes originated from articles which were published in the newspaper or another media. Authors of articles came from large experts, practitioners, intellectuals, men and women, who known active to support civil society movement in Indonesia. Few names are Ahmad Syafii Maarif (intellectual Muslim, former Head of Central Board of Muhammadiyah), Masdar Farid Mas'udi (intellectual Muslim, member of Central Board of Nahdlatul Ulama), and Lies Marcoes-Natsir (activist of Islamic women movement, researcher). Details contents of supplement for each topics are described in Table 1 below.

\section{Table 1. Themes for each topics of supplement of CE textbook at UIN Syarif Hidayatullah, Jakarta}

\begin{tabular}{|l|l|}
\hline \multicolumn{1}{|c|}{ Topics } & \multicolumn{1}{c|}{ Themes } \\
\hline National identity & $\begin{array}{l}\text { 1. National identity and integration } \\
\text { 2. Threats of disintegration } \\
\text { 3. beware on destruction of nationalism } \\
\text { 4. Nationalism must be balanced by inter-ethnics empathic } \\
\text { attitudes }\end{array}$ \\
\hline State & $\begin{array}{l}\text { 1. Islam and nation-state } \\
\text { 2. State, ethnics group, and social conflicts } \\
\text { 3. Multi-ethnics country and conflict resolutions } \\
\text { 4. Common-platform of women movements }\end{array}$ \\
\hline Citizenship & $\begin{array}{l}\text { 1. Citizenship will being lost if ... } \\
\text { 2. Politics is not male sphere }\end{array}$ \\
3. Questions (FAQ) raised about internal displaced persons and \\
refugees
\end{tabular}




\begin{tabular}{|c|c|}
\hline Constitution & $\begin{array}{l}\text { 1. Making new constitution text of UUD } 1945 \\
\text { 2. Constitutional supreme and judicial review } \\
\text { 3. Constitutional supreme must be controlled by people }\end{array}$ \\
\hline Democracy & $\begin{array}{l}\text { 1. Democracy in Indonesia } \\
\text { 2. Islam and democracy in Indonesia } \\
\text { 3. Islam between two democracy models } \\
\text { 4. Presidential elections and democracy } \\
\text { 5. Election and anxiety of turning point of democracy } \\
\text { 6. Decaying political party and democracy } \\
\text { 7. Four eligibilities of press as pillar of democracy in Indonesia } \\
\text { 8. Gendering of democracy } \\
\text { 9. Afghanistan women in the political arena }\end{array}$ \\
\hline $\begin{array}{l}\text { Regional } \\
\text { autonomy }\end{array}$ & $\begin{array}{l}\text { 1. Ideas of province as focus in regional autonomy policy } \\
\text { 2. Reflection on impeachment of head of district (Bupati) of } \\
\text { 3. Do not pressure to religion by way regional regulations } \\
\text { 4. Save Indonesia with Sharia }\end{array}$ \\
\hline $\begin{array}{l}\text { Good } \\
\text { governance }\end{array}$ & $\begin{array}{l}\text { 1. Good governance must be implemented } \\
\text { 2. Interest groups and clean government } \\
\text { 3.Transcperancy and accountability in the modern democracy } \\
\text { 4.Political participation of women and controlling to corruption }\end{array}$ \\
\hline Human rights & $\begin{array}{l}\text { 1. Map of human rights development } \\
\text { 2. Gender analysis } \\
\text { 3.Gender injustice, gender equality and gender mainstreaming } \\
\text { 4. Islam and women reproduction rights } \\
\text { 5. Women spirituality in the religious perspective } \\
\text { 6. Threats of human rights reinforcement }\end{array}$ \\
\hline Civil society & $\begin{array}{l}\text { 1. Civil society and democracy revisited } \\
\text { 2. Future of civil society in Indonesia } \\
\text { 3. Civil society and investment of democracy } \\
\text { 4. Kill to civil society } \\
\text { 5. Political representative of women }\end{array}$ \\
\hline
\end{tabular}

Source: Adapted from ICCE of UIN Syarif Hidayatullah Jakarta (2004)

Islamic values developed as core contents of CE are musyawarah (consultation) for democracy practiced, and, buquq al insaniyah (human rights). Islam and democracy are two political systems which differenced, particularly about defining its concept. According to the authors of CE book texts at UIN Jakarta, Islam has value system which reliable and support the democracy political system (Rosyada, et.al, 2003). Human rights topic has been important to explain that Islamic teachings 
supported and reinforced it in the living actual. Human rights based Islamic values followed to concepts which be developed by Cairo Declaration. Declaration (in Rosyada, 2003) ${ }^{13}$ described what human rights acccording to Islamic teaching primary source, Qur'an, as follows:

1. equity and freedom rights (verses Quran as: al-Isra, 70; an-Nisa', 58, 105, 107, 135; and al-Mumtahanah, 8).

2. rights to life (al-Maidah, 45; al-Isra, 33)

3. rights to self-protection (al-Balad, 12 to 17; at-Tawbah, 6).

4. rights to self-respect (at-Tawbah, 6)

5. rights to maried (al-Baqarah, 221; al-Rum, 21; an-Nisa, 1; at-Tabrim, 6)

6. rights to equity of men and women (al-Baqarah, 228; al-Hujurat, 13).

7. children rights from their parents (al-Baqarah, 233, al-Isra, 23 to 24).

8. rights to education (at-Tawbah, 122; al-'Alaq, 1 to 5).

9. rights to religious freedom (al-Kafirun, 1 to 6; al-Baqarah, 156; al-Kahfi, 29).

10. rights to assylum seeking (an-Nisa, 97; al-Mumtahanah, 9).

11. rights to job (at-Tawbah, 105; al-Baqarah, 286; al-Mulk, 15).

12. rights to equality opportunity (al-Baqarah, 275 to 278; an-Nisa, 161; Ali Imran, 130).

13. proverty rights (al-Baqarah, 29; an-Nisa, 29).

14. prissoner rights (al-Mumtahanah, 8).

Higher Education Institution of Mubammadiyah

Muhammadiyah as large Muslim organization in Indonesia has many education institutions since primary schools to universities and academies. Since early its establishing at 1912, Muhammadiyah has played role important to build civil society movement, especially through education arena. As described in Table 2, Muhammadiyah has social capital to build social society through their education institutions.

13 Dede Rosyada, et.al., Pendidikan Kewargaan, Civic Education: Demokrasi, Hak Asasi Manusia \& Masyarakat Madani (Jakarta: ICCE UIN Jakarta, 2003). 
Table 2. Muhammadiyah's educational institutions.

\begin{tabular}{|c|c|c|}
\hline No. & Level of education institutions & Total \\
\hline \multirow[t]{3}{*}{1} & \multicolumn{2}{|l|}{ Primary Schools : } \\
\hline & Sekolah Dasar (SD) & 1,128 \\
\hline & Madrasah Ibtidaiyah (MI) & 1,768 \\
\hline \multirow[t]{3}{*}{2} & \multicolumn{2}{|l|}{ Secondary Schools : } \\
\hline & Sekolab Menengah Pertama (SMP) & 1,179 \\
\hline & Madrasah Tsanawiyah (MTs) & 534 \\
\hline \multirow[t]{4}{*}{3} & \multicolumn{2}{|l|}{ Senior High/Vocational Schools : } \\
\hline & Sekolab Menengah Atas (SMA) & 509 \\
\hline & Sekolah Menengah Kejuruan (SMK) & 249 \\
\hline & Madrasah Aliyah (MA) & 171 \\
\hline 4 & Higher Education Institutions: University, Academy, Polytechnics & 169 \\
\hline & Total & 5,707 \\
\hline
\end{tabular}

Source: Adapted from Asykuri (2000) in Chamim, et.al. (2003).

Civic education (CE) for Muhammadiyah is necessity and should be developed. Some reasonings why $\mathrm{CE}$ should implementated through educational arena since primary level to university level, those are becaused by :

1. the destruction of democracy and community values.

2. the confusion civic living values of community.

3. the decadence of tolerance values of community

4. the confusion honesty, polite and helpful values.

5. the weaknes of values in family.

6. the practiced of corruption, collution, and nepotism at government.

7. the destrution of living and economics system.

8. abuse to nationalism values (Chamim, et.al., 2003) ${ }^{14}$.

Muhammadiyah saw that CE in schooling models within New Order policy have some weakness in their contents and teaching/learning methods. At higher ecucation level, the content subtances did not focuss to democratic and citizenship education. If there are exists, it had been taught ideally, normatively and legallistically, and so tends to use military perspective. Civics learning did not grow up to optimal becauce the approaches used more indoctrinative and non-

14 Asykuri ibn Chamim, et.al. Civic Education, Pendidikan Kewarganegaraan: Menuju Kebidupan yang Demokratis dan Berkeadaban (Yogyakarta: Majelis Diktilitbang PP Muhammadiyah, LP3 UMY and The Asia Ford Foundation, 2000) 
participative. Another problem is contents or teaching materials more theoritics than practical (contextual), then students failed to have "democracy experience" (Chamim, et. al., 2003, p. xxxv). ${ }^{15}$

Muhammadiyah urged that developing democracy and civil society therough $\mathrm{CE}$ is most strategic way. Education institutions could played role important to the socalization, dissemination, an actualization of concepts, systems, values and democratic cultures. In the multidimensional crisis today in Indonesia, CE roles to democratic climate to finish the crisis.

Some important agendas to develop through CE in higher education institutions of Muhammadiyah are:

1. developing democratic values: justice, abiding rule of law, freedom to expression and association, representatives, gender equity, and majority rules.

2. developing civic and community values: respect to individual rights, local needs, and common good.

3. developing fair government: participation to get service with justice, fairness, check and balances.

4. creating national identity: reorientation of nation building within unity in difference (diversity), independence, and national pride.

5. developing social cohesion: tolerance, social justice and acceptance.

6. developing self-cultivation: truth, law abiding, honesty, civility and helping others.

7. developing economic life, fair competition, wealth, entrepreneurship, and the free market.

8. developing family values: respect, support, protection, moral behavior, gender sensitive, togetherness. ${ }^{16}$

Muhammadiyah has published CE book for university students and lecturers. The book contents the subjects which should be developed intensively in teaching and learning methodologies by lecturers and students with searching some actual cases and local contexts (Chamim, et.al., 2003). ${ }^{17}$ Then, the wirters book agreed that "teaching democracy must be democratically too" (Chamim, et.al., 2003, p. xli). ${ }^{18}$

\footnotetext{
15 Asykuri ibn Chamim, et.al. Civic Education..., Ibid.

16 Ibid.

17 Ibid.

18 Ibid.
} 
The contents teaching of $\mathrm{CE}$ in Muhammadiyah university included topics on civic education and civil society ideality; values democracy, good governance and democratic, transformation of values democracy in the family and community spheres, build national identity, the new world order and globalization, populist and ethos economics as national strengthening bases, and reinforcement of human rights.

Islamic values in CE.

Are Islamic values relevancy with principles of civic education? Another question, what should be done about Islamic values in civic education? Muhammadiyah creatively developed Islam teachings as core of contents the civics teaching resouces into one the textbook titled Civic Education, Pendidikan Kewarganegaraan: Menuju Kebidupan yang Demokratis dan Berkeadaban [Civic Education toward Living Democratic and Civility] (Chamim, et.al., 2003) ${ }^{19}$. Hardwork of teams have contributed the new model and construction of CE with Islamic values based.

Explicitely, the contents of CE developed according to Guidelines of Islamic Life for Muhammadiyah Community (Pedoman Hidup Islami Warga Muhammadiyab). Guidelines were derived Qur'an's teachings based. Guidelines included the way of life for Muhammadiyah members on personal, family, community, organization, mangement of bussines of organisation (amal usaha), developing profession, living to nation and state, consevation of environment, developing of science and technology, and arts and culture (Guidelines in Chamim, et.al., 2003). ${ }^{20}$

According to Muhammadiyah, Islamic values have comfortable to build civil society through CE. For example, when launching the CE book for Muhammadiyah university level, Ahmad Syafii Maarif (Suara Mubammadiyah, 2004, p. 49) ${ }^{21}$ said that "democracy is emanation of shura teachings in Islam" which practiced since early Islamic period. CE Book explicitely used Islamic terms to explain the tranformation democracy values in the family and community arenas. In the family sphere, democracy values internalized normatively as efforted to build sakinah (posperity) family which has three elements, i.e. mahabbah (love with biological-materials oriented), mawaddah (love with immaterial oriented), and rahmah (love with spiritualistic oriented as God Merciful). The Sakinah values in the familiy need to implement in reality used the good modelling (uswah hasanah) as basic ethics education.

19 Ibid.

20 Ibid.

21 Suara Muhammadiyah, 2004, p. 49. 
In the community sphere, normatively doctrine argued that each social community should help each other to virtue action and avoid the "kejahatan/dosa" (sins) action. Islam mentioned it in the sentences as follows: "wa ta'awanu 'ala al-birri wa al-taqwa, wa laa ta'awanu 'ala al-itsmi wa al-udwaan." (mutualism and hellp each other to good virtues, and avoid the wrong/false actions).

\section{Civil Society or "Masyarakat Madani/al-Mujatama' al-Madani"?}

Terminology of civil society has many naming in Indonesian context. It translated as masyarakat sipil, or masyarakat madani following to Arabic translaition [al-mujtama' al-madani], an civil society as well as original text in English. Anwar Ibrahim, former Deputy Prime Minister of Malaysia, has influenced the interpretation of civil society as masyarakat madani. His argument about civil society as masyarakat madani was followed by intellectual Muslim of Indonesia like Nurcholish Madjid, Mohammad Dawam Rahardjo, and Azyumardi Azra. They are categorized as modernist or Islamic campus groups.

According to Nurcholish Madjid (2001), ${ }^{22}$ Islam has potential doctrinal resources on civil society between Quran and traditions (hadiths) of Prophet Muhammad life. Another intellectual Muslim such as Abdurrahman Wahid, Muhammad A.S. Hikam and swing youth intellectual of NU like Ahmad Baso or Ulil Abshar Abdalla tend to agree with civil society terminology as original translation. This has implication to differeciation of interpretation the Islamic historical and texts on creating of Islamic society as khairu ummah (civic virtues, good citizens).

$\mathrm{NU}$ concepts to build civil society are formulated in five principles (kulliyyat alkhams) as the protection of: religious consciousness and observances (bifž $h$ al-din), life

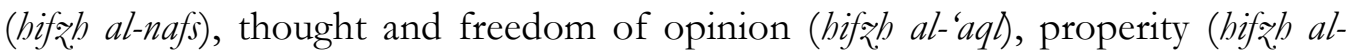
amwa), and enter into marriage and the protection of reproductive rights (bifz $h$ alnas) (Falaakh, 2001).

For Muhammadiyah, civil society translated as masyarakat madani. Its translation has meaning that spirituality dimension of society according to historical context when Prophet Muhammad built the new society. Another argument, masyarakat madani meant "city", "civilized". For that, it has plurality which support the tolerance, heterogenity and diversity in religion/faiths, social, cultural, ethnics and economics.

22 Nurcholish Madjid, "Potential Islamic Doctrinal Resources for the Establishment and Appreciation of the Modern Concept of Civil Society", in Nakamura Mistuo, et.al. (eds.), Islam \& Civil Society in Southeast Asia, (Singapore: Institute of Southeast Asia Studies, 2001) 
In early 2000, Muhammadiyah introduced the Dakwah Kultural (Cultural propagation) became new discourse in Muhammadiyah movement in new millenium (2000). Annual meeting (Sidang Tanwir) of Muhammadiyah in 2003, at Makassar, South Sulawesi, has accepted the Dakwah Kultural as new paradigm of propagation. It appreciated the multiculturalism of Indonesian society which plural based ethnics, religions, arts and subcultur. Dakwah has strategic position for Muhammadiyah, especially when faced the plurality which increased new task. Dakwah kultural for Muhammadiyah is propagation of advocacy like another civil society movement. For that, actors of dakwah kultural have to sinergic between all elements of Muhammadiyah (Jabrohim, 2004). ${ }^{23}$

\section{Closing Remarks}

Developing civic education in the Islamic higher education institutions were new phenomena in Indonesia after 1998. How Islamic values have been internalized in civic education, and then could be core of contents it? Two Islamic institutions which be case studies in this paper are uniquely made new tradition for civic education in Indonesia as Muslims country, they are UIN Jakarta and Muhammadiyah through its education institutions at university level.

However, their experiencing improved and interpreted the Islamic values for civic education contents has played role important toward democratic citizens post authoritarianism under New Order Government in Indonesia. For other Muslims country around the world, developing civic education based Islamic teachings could be model how creativity and open-minded to interpretation of religion sources in the education democracy field.

\section{References}

Barton, Greg. 1997. "Indonesia's Nurcholish Madjid and Abdurrahman Wahid as Intellectual 'Ulama: The Meeting of Islamic Traditionalism and Modernism in Neo-modernist Thought", in Studia Islamika: Indonesian Journal for Islamic Studies, Vol. 4. No. 1.

Bellah, Robert N. 1976. "Religion and the Legitimation of the American Republic", in Robert N. Bellah \& Phillip E. Hammond, (eds) Varieties of Civil Religion. San Francisco, Harper \& Row.

23 Jabrohim, "Sinergi Pelaku Dakwah Kultural", dalam Suara Muhammadiyah, No. 17, Vol. 89, 1-15 September 2004, p. 45. 
Chamim, Asykuri ibn, et.al. 2000. Civic Education, Pendidikan Kewarganegaraan: Menuju Kebidupan yang Demokratis. Yogyakarta: Majelis Diktilitbang PP Muhammadiyah, LP3 UMY and The Asia Ford Foundation.

Falaakh, Mohammad Fajrul. 2001. "Nahdlatul Ulama and Civil Society in Indonesia", in Nakamura Mistuo, et.al. (eds.), Islam \& Civil Society in Southeast Asia. Singapore: Institute of Southeast Asia Studies.

Hefner, Robert. 2000. Civil Islam: Muslims and Democratization in Indonesia. Princeton-Oxford, Princeton University Press.

Ismail, Faisal. 1999. Ideologi Hegemoni dan Otoritas Agama: Wacana Ketegangan Kreatif. Yogyakarta: Tiara Wacana.

Jabrohim. 2004. "Sinergi Pelaku Dakwah Kultural", Suara Muhammadiyah, No. 17, Vol. 89, 1-15 September.

Krissantono, (ed.) 1976. Pandangan Presiden Soebarto tentang Pancasila. Jakarta: CSIS.

Madjid, Nurcholish. 2001. "Potential Islamic Doctrinal Resources for the Establishment and Appreciation of the Modern Concept of Civil Society", in Nakamura Mistuo, et.al. (eds.), Islam \& Civil Society in Southeast Asia. Singapore: Institute of Southeast Asia Studies.

Munawar-Rachman, Buddhy. 1995. "Dari Tahapan Moral ke Periode Sejarah Pemikiran Neo-Modernisme Islam di Indonesia”. Ulumul Qur'an, Vol. VI, No. 3 .

Qodir, Zuly. 2002. "Wajah Islam Liberal di Indonesia: Sebuah Penjajagan Awal”, AlJamiah: Journal of Islamic Studies, Vol. 40, No. 2, July-Dec.

Rosyada, Dede, et.al. 2003. Pendidikan Kewargaan, Civic Education: Demokrasi, Hak Asasi Manusia \& Masyarakat Madani. Jakarta: ICCE UIN Jakarta. 